\title{
Analysis of brominated flame retardants in the aquatic environment: a review
}

\author{
Karla Jagić, Marija Dvoršćak, and Darija Klinčić \\ Institute for Medical Research and Occupational Health, Zagreb, Croatia
}

[Received in July 2021; Similarity Check in July 2021; Accepted in November 2021]

\begin{abstract}
The most common and consequently analysed brominated flame retardants (BFRs) are polybrominated biphenyls (PBBs), polybrominated diphenyl ethers (PBDEs), tetrabromobisphenol A (TBBPA), tetrabromobisphenol S (TBBPS), and hexabromocyclododecane (HBCD). As these persistent organic pollutants are widespread in the environment and have a number of harmful effects on human health, the production and use of most has been banned for several years. The aquatic environment is polluted by these compounds through their deposition from the atmosphere, sewage sludge, wastewater treatment plants, and landfills, and higher levels are found in areas with developed industry and agriculture and near landfills. Each compound also seems to show preference for specific compartments of the aquatic environment, i.e. water, sediment, or aquatic organisms, according to their physicochemical properties. The aim of this review was to take a closer look at the analysis of BFRs, as without reliable analysis we would not be able to determine their levels and distribution across the aquatic compartments and assess human exposure and health risks. Particularly worrying are the health risks associated with PBDEs in fish, whose levels generally exceed the permitted values.
\end{abstract}

KEY WORDS: hexabromocyclododecane; HBCD; persistent organic pollutants; PBBs; polybrominated biphenyls; PBDEs; polybrominated diphenyl ethers; TBBPA; tetrabromobisphenol A; TBBPS; tetrabromobisphenol S

Brominated flame retardants (BFRs) are organic compounds that had been on the market for quite a while due to high efficiency and low cost (1). The most common and consequently analysed among them were polybrominated biphenyls (PBBs), polybrominated diphenyl ethers (PBDEs), tetrabromobisphenol A (TBBPA), its analogue tetrabromobisphenol S (TBBPS), and hexabromocyclododecane (HBCD) (Figure 1). They used to be added to textiles, plastic, building materials, and electrical and electronic equipment to prevent fire outbreak or slow down its spread. PBBs, PBDEs, and HBCD were used as additives, while TBBPA was mostly used as a reactive flame retardant (about $80 \%$ of its production), which unlike additives, chemically bind to the materials they protect. However, both types are released into the surrounding air, soil, dust, and water during use, disposal, and/or recycling of materials to which they have been added $(1-4)$.

Since the beginning of their use in the 1960s and 1970s, BFR levels have risen sharply in all parts of the environment (soil, water, and sediment), animals, and humans. Because of their toxicity to humans and animals, persistence in the environment, and a tendency to bioaccumulate and biomagnify in terrestrial and marine food chains, they are considered persistent organic pollutants (POPs) $(1,4-6)$.

Corresponding author:Marija Dvoršćak, Institute for Medical Research and Occupational Health, Ksaverska cesta 2, 10000 Zagreb, Croatia, E-mail: mdvorscak@imi.hr
Annex A of the Stockholm Convention on Persistent Organic Pollutants (7) has listed hexabromobiphenyl (HBB), HBCD, tetra-, penta-, hexa-, hepta-, and deca-BDE as pollutants whose production, use, import, and export are to be eliminated by countries signing the Convention to protect human health and the environment.

Polybrominated biphenyls were used mainly back in the 1970s. There are 209 PBB congeners, which differ in the position and number of bromine atoms attached to the two benzene rings (8). The most widely used PBB congeners were hexa-, octa- and deca-BB (9). They are lipophilic compounds with logarithmic values of the $n$-octanol/water partition coefficient (log Kow) ranging from 5.53 for mono-BB to 9.10 for deca-BB (4). HBB was banned shortly after a mixture of PBBs with its highest proportion was accidentally added to animal feed in Michigan in 1973, and contamination with it spread to agricultural products. PBBs can cause cancer and impair the immune system and brain development $(4,6,10)$.

Polybrominated diphenyl ethers came into use in the 1960s and 1970s. They also have 209 congeners (11) and were the second most represented BFRs in the global market with a share of $33 \%$ (12). They are lipophilic, with a log Kow ranging from 5.08 for mono-BDE to 8.70 for deca$\mathrm{BDE}$ and water solubility ranging from 0.00087 to $0.04 \mathrm{mg} / \mathrm{L}$ at $25{ }^{\circ} \mathrm{C}$. In general, log Kow values increase with the number of bromine atoms, while water solubility and vapour pressure decrease. In other words, increasing the degree of bromination reduces the ability of congeners 


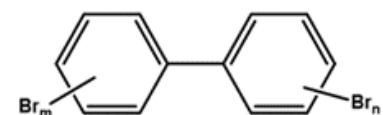<smiles>O=S(=O)(c1cc(Br)c(O)c(Br)c1)c1cc(Br)c(O)c(Br)c1</smiles><smiles>BrC(Br)CCC(Br)CCC(Br)C(Br)CCC(Br)C(Br)Br</smiles>

Figure 1 PBBs, PBDEs, TBBPA, TBBPS, and HBCD structure

to dissolve in water, and higher brominated PBDEs more easily adsorb onto particles in water $(13,14)$ and the organic fraction of sediments. This is how they enter organisms, bioaccumulate in lipid-rich tissues, and biomagnify along the food chain (3). PBDEs are endocrine disruptors and as such interfere with the normal hormonal function in animals and humans (15). Some of the consequences are lower intelligence quotient (IQ), lower cognitive and motor function, and hyperactive and aggressive behaviour (3).

Tetrabromobisphenol $\mathrm{A}$ is a brominated bisphenol A (BPA). It is lipophilic, with a $\log \mathrm{Kow}$ value of 4.5 and a water solubility from 0.17 to $4.2 \mathrm{mg} / \mathrm{L}$ at $25{ }^{\circ} \mathrm{C}(1,13)$. There is no report describing the exact time when its production began, but nowadays it is one of the most widely used BFRs $(16,17)$. Due to its physicochemical properties, TBBPA bioaccumulates in organisms less than PBDEs but remains in water, in which it is therefore more often analysed $(13,18)$. Like PBDEs, TBBPA also disrupts the endocrine system and also affects the immune and nervous system, kidneys, liver, and reproductive development (19, 20).

Tetrabromobisphenol $\mathrm{S}$ has recently been introduced in the market to replace TBBPA (21) and, like TBBPA, it is less prone to bioaccumulation in organisms $(19,22)$. It is lethal even at very low concentrations, disrupts the endocrine system, and directly or indirectly causes hepatotoxicity and cancer (23).

Hexabromocyclododecane is a brominated cyclic alkane most often added to thermoplastic polymers in styrene resins (1). Its commercially available mixture consists of several isomers, most notably $\alpha$-, $\beta$-, and $\gamma$-HBCD (24). Like most other BFRs, HBCD is lipophilic, with a $\log \mathrm{Kow}$ of 5.6, poorly soluble in water $\left(0.002\right.$ to $0.03 \mathrm{mg} / \mathrm{L}$ at $\left.25^{\circ} \mathrm{C}\right)$, and prone to bioaccumulation $(1,13)$. Due to its physicochemical<smiles>Brc1ccc(Oc2ccccc2)cc1</smiles><smiles>CC(C)(c1cc(Br)c(O)c(Br)c1)c1cc(Br)c(O)c(Br)c1</smiles>

properties, it is found at much higher levels in sediment than in water, where it is often undetectable (20). HBCD is neurotoxic and toxic to the thyroid (19), and according to some research it has also been identified to act as an endocrine disruptor $(24,25)$.

The development of cities, industry, agriculture, and tourism has significantly increased the levels of POPs in the aquatic environment. In 2000, the European Union (EU) Directive 2000/60/EC (26) introduced special measures against water pollution by individual pollutants or groups of pollutants which pose a significant risk to the aquatic environment, including sources of drinking water. These measures were aimed at gradually reducing POP production and at phasing out priority hazardous substances within 20 years to lower the concentrations of naturally occurring substances in the marine environment to near background levels and the concentrations of synthetic substances to zero. The list of priority hazardous substances, which included PBDEs since 2000 (26), has in the meanwhile been amended to include HBCD since 2013 (27). According to Directive 2013/39/EC, the maximum allowable concentration of Environmental Quality Standard (EQS) for PBDEs (BDE-28, -47, -100, -99, -153, and -154) in inland surface waters (rivers, lakes and related artificial or significantly altered water bodies) is $0.14 \mu \mathrm{g} / \mathrm{L}$ and in other surface waters $0.014 \mu \mathrm{g} / \mathrm{L}$. The maximum allowable concentrations for HBCD were set to 0.5 and $0.05 \mu \mathrm{g} / \mathrm{L}$, respectively, and the average annual concentrations to 0.0016 and $0.0008 \mu \mathrm{g} / \mathrm{L}$, respectively (27).

Water, sediment, and suspended particles in water are the main routes of exposure to POPs for aquatic organisms (28). Considering that PBDEs and HBCD are hydrophobic, difficult to detect in water even with the most advanced analytical instruments, and prone to bioaccumulation and 
biomagnification (24), aquatic organisms often serve as indicators of pollution with these compounds (29). According to the Directive 2013/39/EU (27), the EQS for PBDEs in biota (fish) is $0.0085 \mathrm{ng} / \mathrm{g}$ wet weight (ww) and refers to the sum of congeners BDE-28, $-47,-99,-100,-153$, and -154 . The EQS for HBCD is $167 \mathrm{ng} / \mathrm{g}$ ww. These values represent the upper limits above which these compounds are considered toxic to the aquatic environment and organisms.

POPs can be detected in the environment at levels that pose a significant risk for decades after measures have been taken to reduce or completely stop their production. The reason is that products containing these compounds are still being used and will remain the source of pollution throughout their lifetime and long after they have been disposed at landfills or recycled.

This short review presents the analytical procedures used to determine PBBs, PBDEs, TBBPA, TBBPS, and $\mathrm{HBCD}$ in the aquatic environment (water, sediment, and organisms) and their concentrations around the world.

\section{CHEMICAL ANALYSIS}

Quantitation of PBBs, PBDEs, TBBPA, TBBPS, and HBCD in environmental and biological samples takes highly sensitive and accurate methods to detect levels most often expressed in $\mathrm{ng} / \mathrm{g}$ or $\mathrm{ng} / \mathrm{L}$. Another challenge is how to prepare samples with complex matrices, especially biological samples with a higher fat content, such as fish. Preparation requires exhaustive and selective extraction, purification, and concentration of the sample before final instrumental analysis. Depending on the type of chromatography and detection technique used, the procedure may also require fractionation of compounds during purification to prevent co-elution of interfering compounds with the target analytes.

Particularly demanding is the determination of decabromodiphenyl ether (BDE-209) $(3,14,30)$. It is nonvolatile and quickly decomposes to hepta-, octa-, and nonaBDE and brominated dibenzofurans at high temperatures or in the presence of UV light. Under UV light octa- and nona-BDE can further degrade to more stable lower brominated BDE congeners. Samples and extracts should therefore be protected from UV light throughout the analytical process, usually with tinted (brown) glassware and vials, and by wrapping the dishes in aluminium foil. In addition, BDE-209 behaves differently from other PBDE congeners in the ion source of mass spectrometry (MS).

\section{Sampling, sample processing, and storage}

Sample collection, preparation, and storage are important steps before extraction, as they need to minimise the risk of contamination or thermal and photolytic degradation of individual compounds. The sampling site must be selected carefully to obtain samples representative of the tested area. Wastewater samples need to be collected downstream or upstream of urbanised areas or industrial plants to reflect changes in water composition. Drinking water, in turn, should be collected at the midstream of rivers at a depth of 20 to $50 \mathrm{~cm}$ (15). Samples of seawater and lake water are collected at the same depth $(13,31)$. Depending on the sensitivity and limit of detection (LOD) of the analytical method, the volume of collected water can range from $50 \mathrm{~mL}$ to $20 \mathrm{~L}$. Collection bottles should be pre-washed with distilled deionised water and an organic solvent, usually methanol (15). After collection, water samples are filtered through a $0.45 \mu \mathrm{m}$ pore size membrane and stored at $4{ }^{\circ} \mathrm{C}$ in brown glass bottles to minimise photolytic degradation or biodegradation of the compounds. Analysis is usually performed within 48 hours $(12,15,19$, $20,32)$. The optimal volume required for analysis with gas chromatography (GC) coupled with tandem mass spectrometry (MS/MS) or with liquid chromatography (LC) coupled with MS/MS is from $0.250 \mathrm{~mL}$ to $1 \mathrm{~L}(2,13,15$, 19, 31, 32). Sometimes, samples can be collected and extracted at the same time with passive samplers, such as the polar organic chemical integrative sampler (POCIS) or with the diffusive gradients in thin films (DGT) technique, which consists of a diffusive agent and a binding agent (sorbent). The best sorbent for TBBPA is a mesoporous silica-based imprinted polymer, as it shows good selectivity and affinity $(15,33)$.

Water samples can be adjusted to the required $\mathrm{pH}$, usually $\sim 2$, by adding $1 \%(v / v)$ formic acid, diluted sulphuric acid, or diluted hydrochloric acid. Acidification of water samples reduces precipitation, microbial activity, and loss of analyte due to sorption onto the bottle. Wastewater samples can be acidified only after they have been filtered. Chlorine present in tap water samples is most often removed with sodium thiosulphate $(15,19)$.

Biological samples are lyophilised and homogenised before extraction and stored at $-20{ }^{\circ} \mathrm{C}(6,34,35)$.

Sediment samples are usually collected by taking a few subsamples at one location of interest, which are then combined and homogenised to obtain a representative composite sample for that location. Additionally, if sediment cores are collected, they can be stratified by sediment depth to obtain data for targeted analytes at a certain time estimated from the sedimentation rate at a location. Sediments are usually stored at $-20{ }^{\circ} \mathrm{C}$ until analysis (13, $32,36,37)$.

\section{Extraction techniques}

The first step in the analysis of target compounds in environmental and complex biological samples is to extract them with minimal loss and minimal consumption of time and chemicals. Sample volume will depend on the levels of target compounds in it and the sensitivity of the analytical technique. Unlike environmental samples (water and sediment), biological samples (fish and seafood) have a 
Table 1 Review of methods used to analyse brominated flame retardants in environmental samples

\begin{tabular}{|c|c|c|c|c|c|}
\hline Sample & Compounds & $\begin{array}{l}\text { Extraction } \\
\text { technique }\end{array}$ & Extract purification & Detection technique & Ref. \\
\hline \multirow{15}{*}{ Water } & PBDE & USAEME & 1 & GC-EI-MS & (31) \\
\hline & PBDE & SPE & 1 & GC-ECD & (12) \\
\hline & PBDE & UA-DLLME & l & HPLC-UV & $(6)$ \\
\hline & PBDE & SBSE & 1 & GC-EI-MS & $(42)$ \\
\hline & PBDE & LLE & 1 & GC-EI-MS & (32) \\
\hline & PBDE & SPE & silica gel/aluminium oxide or Florisil ${ }^{\circledR}$ & GC-EI-HRMS & (13) \\
\hline & TBBPA, TBBPS & SPME & 1 & HPLC-UV & $(22)$ \\
\hline & TBBPS & MSPE & 1 & HPLC-UV & (41) \\
\hline & TBBPA & US-DLLME & 1 & HPLC-UV & (44) \\
\hline & TBBPA & SPE & 1 & HPLC-UV & (33) \\
\hline & TBBPA & MSPE & 1 & HPLC-UV & (2) \\
\hline & TBBPA, TBBPS & LLE & 1 & HPLC-ICP-MS/MS & (19) \\
\hline & TBBPA, HBCD & DI-SPME & 1 & HPLC-ESI-MS & $(20)$ \\
\hline & TBBPA, HBCD & SPE, PLE & silica gel/aluminium oxide or Florisil ${ }^{\circledR}$ & LC-MS/MS & (13) \\
\hline & TBBPA, HBCD & PLE & SPE & LC-ESI-MS/MS & (37) \\
\hline \multirow{11}{*}{ Sediment } & PBDE & UAE & SPE & GC-EI-MS & $(40)$ \\
\hline & PBDE & PLE & silica gel/aluminium oxide or Florisil ${ }^{\circledR}$ & GC-EI-HRMS & (13) \\
\hline & PBDE & Soxhlet & silica gel & GC-EI-MS & (32) \\
\hline & PBDE & Soxhlet & GPC/silica gel & GC-HRMS & (46) \\
\hline & PBB, PBDE & Soxhlet & multilayer silica gel & HRGC-HRMS/GC-ECD & $(10)$ \\
\hline & PBB, PBDE & UAE & silica gel & GC-EI-MS & $(52)$ \\
\hline & HBCD & Soxhlet & multilayer silica gel & HPLC-MS/MS & $(55)$ \\
\hline & TBBPA, HBCD & PLE & SPE & LC-ESI-MS/MS & (37) \\
\hline & TBBPA, HBCD & UAE & silica gel/aluminium oxide or Florisil ${ }^{\circledR}$ & LC-MS/MS & (13) \\
\hline & TBBPA & Soxhlet, LLE & silica gel & HPLC-ESI-MS/MS & (36) \\
\hline & TBBPA & Soxhlet & silica gel & HPLC-ESI-MS & $(61)$ \\
\hline
\end{tabular}

DI-SPME - direct immersion solid phase microextraction; ECD - electron capture detector; EI - electron ionisation; ESI - electrospray ionisation; GC - gas chromatography; HBCD - hexabromocyclododecane; HPLC - high performance liquid chromatography; HRGC - high resolution gas chromatography; HRMS - high resolution mass spectrometry; ICP - inductively coupled plasma; LC - liquid chromatography; LLE - liquid-liquid extraction; MS - mass spectrometry; MS/MS - tandem mass spectrometry; MSPE - magnetic solid phase extraction; PBB - polybrominated biphenyls; PBDE - polybrominated diphenyl ethers; PLE - pressurized liquid extraction; SBSE - stir bar sorptive extraction; SPE - solid phase extraction; SPME - solid-phase microextraction; TBBPA - tetrabromobisphenol A; TBBPS - tetrabromobisphenol S; UAE - ultrasound-assisted extraction; UA-DLLME - ultrasound-assisted dispersive liquid-liquid microextraction; USAEME - ultrasound-assisted emulsification microextraction; US-DLLME - ultrasound-dispersive liquid-liquid microextraction; UV - ultraviolet detection

high content of organic matter, protein, and lipids (35). Lipids should therefore be dissolved with a suitable solvent (34). Emulsions are often treated with a (Tris)-citrate buffer to improve separation of the organic and aqueous phases. The remaining emulsion is often treated with $25 \% \mathrm{KOH}$ in methanol (35). Despite differences in matrix composition, the same or similar combinations of extraction techniques and solvents are used to analyse BFRs in environmental and biological samples, and the procedure usually differs in extract purification (34).

\section{Extraction of BFRs from water samples}

The most common techniques used to extract BFRs from water samples are liquid-liquid extraction (LLE) and solid phase extraction (SPE). Recently, these have been expanded to include solid-phase microextraction (SPME), stir bar sorptive extraction (SBSE), dispersive liquid-liquid microextraction (DLLME), and ultrasound-assisted emulsification microextraction (USAEME), which minimise or completely get rid of the use of extraction solvent $(6,12,15,19,20,31)$.

The main disadvantages of LLE are high solvent consumption and a need for repeated extraction to ensure detection of target compounds present at trace levels in 
water samples. During extraction of target compounds from wastewater, an emulsion can be formed, which further complicates the procedure $(15,34)$. LLE most often uses dichloromethane, $n$-hexane, or a mixture of $n$-hexane and dichloromethane $(1: 1, v / v)$ to extract PBDEs from natural and wastewater samples $(15,32)$. Dichloromethane is also used to extract TBBPA and TBBPS from river, sea, and tap water (19).

Another classic technique still widely used to analyse BFRs at trace levels in water samples is SPE. This technique is based on the sorption of the analyte on a sorbent placed in a disk or column. When the liquid sample is passed through such a column, the compounds of interest are bound to the sorbent and subsequently eluted from the sorbent with an appropriate volume of a suitable solvent. SPE is widespread because it can handle larger sample volumes, reduces solvent consumption, and allows all types of solvents $(13,15)$. An additional advantage is that, with a suitable sorbent and solvent, it can separate analytes from the sample matrix and purify and concentrate the extract in one step (12). Using SPE and the commercially available ABS Elut-NEXUS ${ }^{\circledR}$ - an ultraclean polymeric sorbent which has bimodal porosity and a high surface area-Suzuki and Hasegawa (38) extracted TBBPA and $\alpha-, \beta$-, and $\gamma$-HBCD with acceptable recovery. Also, an automated SPE technique has been developed to determine TBBPA and HBCD in seawater (13). It relies on a styrene divinyl benzene disk (SDB-XC, 3M) and accelerated solvent extraction (ASE) with dichloromethane and $n$-hexane (1:1, $v / v$ ). One study (12) compared three types of commercially available sorbents - Oasis HLB ${ }^{\circledR}$, Isolute ${ }^{\circledR} \mathrm{C} 18$, and Isolute ${ }^{\circledR}$ $\mathrm{PAH}$ - for extraction of PBDEs from wastewater. Although the first two sorbents are often used to extract and purify PBDEs from environmental samples $(12,13,39)$ Isolute $^{\circledR}$ PAH with ethyl acetate as eluent stands out as the best method due to the lowest interference and chromatogram baseline. The reason may be that Isolute ${ }^{\circledR} \mathrm{PAH}$ uniquely combines a $\mathrm{C}_{18}$ and an amino-based sorbent.

Recently, molecularly imprinted polymers (MIP) have attracted the attention of researchers due to their high selectivity for target analytes. The structure of imprinted polymers contains selective cavities that correspond to target analytes in size and shape $(2,40)$. If magnetised, molecularly imprinted polymers can easily be separated with a magnet and used in magnetic solid phase extraction (MSPE). This method was successfully applied by $\mathrm{Hu}$ et al. (2) to determine TBBPA in water samples with methanol as solvent and by Wang et al. (41) to determine TBBPS with a methanol and water $(3: 7, v / v)$ mixture as solvent. In certain cases, the desired structure of the imprinted polymers may be expensive or the molecules from which the imprinted polymers are made may not dissolve in the required solvent. In these cases, the alternative is to use chemical compounds of similar structure or structural analogues, also known as dummy molecularly imprinted polymers (DMIP).
SPME is a very effective, simple, and fast technique for extracting targeted compounds from liquid samples without the use of solvents. It uses extraction fibres coated with a polymer or sorbent and can be coupled to chromatographic techniques to achieve the needed extract concentration and introduce the sample into the detection system. Although the surface area of the fibre is small, it ensures sufficiently low LOD of trace organic compounds in water samples (15). Fibre selection is a key for successful extraction. One of the best choices are fibres coated with synthetic mesoporous cellular foams (MCFs) because of their large pores. They are superior to commercial sorbents in terms of TBBPA and TBBPS adsorption and extraction from water samples (22). SPME is rarely used for the analysis of $\alpha$-, $\beta$-, and $\gamma$-HBCD diastereoisomers in water samples. One exception is direct immersion of the SPME fibres coated with a polydimethylsiloxane/divinylbenzene sorbent (PDMS/DVB), which yields good extraction and determination of TBBPA, HBCD diastereoisomers, and PBDEs with relatively high molecular weight and low vapour pressure. Better recoveries with SPME can also be achieved with headspace (HS) extraction by exposing fibres to the vapour above the sample instead of immersion, which prolongs fibre lifetime and prevents contamination with non-volatile compounds. This HS-SPME technique is suitable for the extraction of PBDEs with lower molecular weights and higher vapour pressures $(15,20,34)$.

Another technique based on the fibre-coating sorbent is SBSE. It allows the use of greater amounts of sorbents than SPME, which increases sorption capacity, extraction, and sensitivity, and the method is robust and easy to perform (15). Compounds of interest are sorbed onto polydimethylsiloxane fibre coating by immersing a magnetic plate directly into the liquid sample or by exposing it to vapour above the sample (HS technique) for a while. Stirring the magnetic plate accelerates sorption. The compounds are then chemically or thermally desorbed and introduced directly into the chromatograph $(15,42)$. SBSE with polydimethylsiloxane is good for extraction of tri- to hexa-BDEs (34). For higher brominated BDEs, which are thermally less stable, a better technique is liquid desorption (LD) $(42,43)$.

The DLLME technique is based on the dispersion of extract droplets in aqueous solution with a suitable dispersion solvent $(6,15)$. The extraction solvent must be denser than water (44) and the dispersion solvent must be mixed with both the extraction solvent and the aqueous solution to form a cloudy solution that increases the interaction between the two phases to yield better extraction. This technique is fast, efficient, simple, and requires low solvent consumption (6). DLLME provides good repeatability, and its efficiency can be enhanced by the use of ultrasound to obtain as homogeneous a cloudy solution as possible (US-DLLME) $(6,44)$. It is suitable for the extraction of TBBPA from water samples using tetrahydrofuran as dispersion solvent and chloroform as 
extraction solvent (44) and for the extraction of PBBs using carbon tetrachloride as extraction solvent and acetonitrile as dispersion solvent (6).

The USAEME technique is based on the emulsification of an organic solvent, which then extracts the desired compounds from the water sample using ultrasound. It is a simple and non-expensive method that allows simultaneous extraction and concentration before GC analysis (15). USAEME efficiency is similar to that of LLE, SPME, or SBSE but results in lower LODs than SPME. It has successfully been applied for the extraction of trace PBDEs in water samples (31).

\section{Extraction of brominated flame retardants from sediment and biological samples}

Classic techniques for BFR extraction from sediment and biological samples are solid-liquid extraction (SLE) and Soxhlet extraction. The most frequent of more recent techniques are ultrasound-assisted extraction (UAE), microwave-assisted extraction (MAE), and pressurised liquid extraction (PLE). The last is also known as accelerated solvent extraction (ASE), as it significantly decreases extraction time and solvent consumption, can be automated or semi-automated, and can process a large number of samples at the same time $(13,36,40,45-49)$.

SLE is used to extract BFRs from fish and seafood samples. It is based on the same principle as LLE, except that target analytes are extracted from solid matrices. For example, PBDEs are extracted from bivalve samples by adding $1 \mathrm{~mol} / \mathrm{L} \mathrm{KOH}$ to form aqueous phase, and then by adding a mixture of $n$-hexane and methyl tert-butyl ether $(1: 1, v / v)(13)$. From fish samples they are extracted with a mixture of cyclohexane and isopropanol $(1: 1, v / v)(49)$. As for TBBPA extraction, Hu et al. (2) reported a successfully applied combination of SLE and MSPE. More precisely, TBBPA was extracted from fish with acetonitrile, the supernatant evaporated to dryness, and second extraction completed with a mixture of methanol and water $(1: 1, v / v)$ and magnetised MIP as adsorbent.

The second BFR extraction classic from solids such as sediment and biological samples is Soxhlet extraction. It is a simple technique that requires minimal sample preparation but also large volumes of solvents, usually dichloromethane or acetone $/ n$-hexane or dichloromethane and $n$-hexane mixtures $(45,46,50)$. In addition, extraction takes more than $20 \mathrm{~h}$ (34). Despite its shortcomings, Soxhlet extraction serves as the benchmark for evaluating the efficiency of other extraction techniques $(34,45)$ because it achieves high yields for PBDEs, HBCD, and TBBPA and good repeatability for both sediment and biological samples. Water-miscible solvents, such as acetone or methanol, should be added to wet sediment samples to improve solvent penetration into the matrix and ensure extraction of BFRs (34). For sediment samples, the best recoveries for PBDEs, HBCD, and TBBPA are obtained with a solvent mixture of acetone and $n$-hexane at different ratios $(1: 1$ or $1: 3, v / v)(32$, $34,45,51)$. Dichloromethane is used to extract PBBs from fish samples (50) and a mixture of $n$-hexane and dichloromethane $(1: 4, v / v)$ to extract both PBDEs and PBBs from sediment (10).

UAE is a simple extraction procedure facilitated by ultrasound passing through the sample and organic solvent. It is relatively fast, can process several samples at once, and does not require expensive instruments. Its disadvantages are high solvent consumption and low efficiency, which is why repeated extractions are sometimes needed to extract enough analytes. However, the method has been successful in extracting PBDEs from sediment and bivalve samples with a solvent mixture of dichloromethane and $n$-hexane $(1: 1, v / v)(13)$ and in extracting PBDEs and PBBs from sediment with a solvent mixture of $n$-hexane and acetone $(4: 1, v / v)(52)$. It has also been successfully combined with SPE and DMIP to purify and concentrate PBDEs from sediment (40). Even though it is generally used for extraction from solid samples, recently it has also been combined with microextraction techniques for the analysis of liquid samples (53).

MAE accelerates and enhances extraction by microwaveheating the solvent and the sample, which increases analyte yield. The procedure can be automated and allows for simultaneous processing of a larger number of samples (45). However, its main disadvantage is that it also extracts other, interfering lipophilic compounds, which can make purification difficult. This problem can be overcome with gel permeation chromatography (GPC), which separates analytes by size, followed by GC coupled with ion trap tandem mass spectrometry (ITD-MS/MS). With larger initial sample masses and large volume injection (LVI), this technique can have recovery and repeatability comparable to automatic Soxhlet extraction, but the LODs can be 10 times lower (34). He et al. (48) compared the effectiveness of three solvent mixtures [ethyl acetate and cyclohexane $(1: 1, v / v)$, dichloromethane and $n$-hexane $(4: 1, v / v)$, and $n$-hexane and acetone $(1: 1, v / v)]$ for the extraction of PBDEs from fish samples, and the $n$-hexane/acetone mixture (1:1, $v / v$ ) yielded the best results. MAE has also been successful in extracting $\alpha$-, $\beta$-, and $\gamma$-HBCD from sediment samples (54).

The PLE (aka ASE) technique uses high pressure and temperature above solvent's boiling point to increase extraction kinetics and significantly reduce extraction time and solvent consumption (45). This technique has been successfully applied for the extraction of PBDEs, TBBPA, and HBCD from sediment with dichloromethane or a mixture of dichloromethane and $n$-hexane $(13,34,37)$ as well as for the extraction of PBDEs, PBBs, TBBPA, and HBCD from fish $(34,37,47)$.

Wang et al. (45) compared the extraction efficiency of Soxhlet, MAE, and PLE for extracting PBDEs from fish with the $n$-hexane/acetone mixture $(1: 1, v / v)$. The results with MAE and PLE were comparable or even better than 
with Soxhlet extraction, but PLE showed somewhat lower repeatability than MAE (45). Novak et. al. (35), in turn, compared the extraction efficiency of SLE, MAE, and UAE for the extraction of PBDEs from lyophilised mussel samples. UAE proved to be the most effective with tetramethylammonium hydroxide as solvent, while MAE was the least effective. In another study (53), UAE also showed better extraction yields for HBCD and TBBPA from sediments than PLE.

\section{Purification and fractionation}

In addition to targeted compounds, extracts contain other halogenated organic compounds, and complex matrices (from sediment and biological samples), which can affect selectivity and separation efficacy in the chromatograph. This, in turn, increases analytical uncertainty and reduces accuracy and precision of the procedure. Extracts should therefore be purified to separate target compounds from the matrix and other interfering compounds, which is often quite challenging.

Depending on the type of analyte and sample, purification may require one or more steps. Sediment extracts usually contain high concentrations of elemental sulphur, which can interfere with the determination of BFRs. The retention time of elemental sulphur on the GC column can be equal to the retention time of the analysed compounds, but also elemental sulphur may disrupt the operation of the MS. Elemental sulphur is most often removed by adding $\mathrm{Cu}$ powder directly to the sample or extract $(32,34,52)$.

Biological samples contain fats that are extracted together with targeted compounds, and they must be removed before further instrumental analysis. This is usually done using destructive methods with acids, because BFRs are stable under acidic conditions. The simplest way is to add sulphuric acid directly to the extract $(34,47,49)$. Lipids can also be removed with non-destructive methods, such as GPC. With more complex matrices, it is sometimes also necessary to apply adsorption chromatography. The most common fat sorbents used in adsorption chromatography are Florisil ${ }^{\circledR}$ (silicic acid and magnesium salt), aluminium oxide, and silica gel that can be used as acidic, neutral, or basic silica gel (which may cause a loss of $\mathrm{Br}$ atoms in higher brominated BFRs such as HBCD, PBDEs, and PBBs) or a combination of all three $(34,45)$. If necessary, it is possible to combine several columns with different sorbents. Selection of a suitable eluent and sorbent ensures simultaneous purification and separation of extracted compounds into several fractions containing one or more classes of compounds. Columns with the appropriate sorbent can be prepared in the laboratory, but many are also commercially available.

Table 2 Review of methods used to analyse brominated flame retardants in biological samples

\begin{tabular}{|c|c|c|c|c|c|}
\hline Sample & Compounds & $\begin{array}{l}\text { Extraction } \\
\text { technique }\end{array}$ & Extract purification & $\begin{array}{l}\text { Detection } \\
\text { technique }\end{array}$ & Ref. \\
\hline \multirow{10}{*}{ Fish } & PBDE & $\begin{array}{l}\text { QuEChERS with } \\
\text { ultrasound }\end{array}$ & SPE & GC-ICP-MS/MS & $(57)$ \\
\hline & PBDE & SLE & $\mathrm{H}_{2} \mathrm{SO}_{4}$ (conc.) & GC-EI-MS & (49) \\
\hline & PBDE & Soxhlet & GPC/silica gel & GC-HRMS & (46) \\
\hline & PBDE & MAE & GPC/SPE & GC-MS & (48) \\
\hline & PBDE & Soxhlet, PLE, MAE & silica gel & $\begin{array}{l}\text { HRGC-EI- } \\
\text { HRMS }\end{array}$ & $(45)$ \\
\hline & PBDE, PBB & PLE & $\mathrm{H}_{2} \mathrm{SO}_{4}$ (conc.)/aluminium oxide & GC-NCI-MS & $(47)$ \\
\hline & PBDE, PBB & SLE & aluminium oxide & HRGC-HRMS & (56) \\
\hline & PBB & Soxhlet & GPC/silica gel/aluminium oxide & $\begin{array}{c}\text { GC-ECD, } \\
\text { GC-MS/MS }\end{array}$ & $(50)$ \\
\hline & TBBPA & SLE, MSPE & / & HPLC-UV & (2) \\
\hline & TBBPA, HBCD & PLE & SPE & LC-ESI-MS/MS & (37) \\
\hline \multirow{2}{*}{$\begin{array}{l}\text { Bivalves and } \\
\text { fish }\end{array}$} & PBDE & SLE, MAE, UAE & Florisil $^{\circledR}$ & GC-ICP-MS & $(35)$ \\
\hline & PBDE & QuEChERS & SPE, GPC & GC-EI-MS/MS & (39) \\
\hline \multirow{2}{*}{ Bivalves } & PBDE & SLE & $\begin{array}{c}\text { silica gel/aluminium oxide or } \\
\text { Florisil }^{\circledR}\end{array}$ & GC-HRMS & (13) \\
\hline & TBBPA, HBCD & UAE & $\begin{array}{l}\text { silica gel/aluminium oxide or } \\
\text { Florisil }^{\mathbb{B}}\end{array}$ & LC-MS/MS & (13) \\
\hline
\end{tabular}

ECD - electron capture detector; EI - electron ionisation; ESI - electrospray ionisation; GC - gas chromatography; HBCD hexabromocyclododecane; HPLC - high performance liquid chromatography; HRGC - high resolution gas chromatography; HRMS - high resolution mass spectrometry; ICP - inductively coupled plasma; LC - liquid chromatography; MAE - microwave assisted extraction; MS - mass spectrometry; MS/MS - tandem mass spectrometry; $\mathrm{NCI}$ - negative chemical ionisation; $\mathrm{PBB}$ - polybrominated biphenyls; PBDE - polybrominated diphenyl ethers; PLE - pressurized liquid extraction; QuECHERS - Quick, easy, cheap, effective, rugged, and safe technique; SLE - solid-liquid extraction; TBBPA - tetrabromobisphenol A; UAE - ultrasound-assisted extraction; $\mathrm{UV}$ - ultraviolet detection 


\section{Qualitative and quantitative analysis}

The choice of the chromatographic method will depend on the physicochemical properties of target analyte. $\mathrm{GC}$ is suitable for the analysis of volatile and semi-volatile compounds, and their separation on the GC column is guided by their difference in volatility. LC is suitable for the analysis of thermally unstable compounds and those that are difficult to convert into the gaseous phase.

GC coupled to an MS detector (GC-MS) or an electron capture detector (GC-ECD) is the most common method to determine PBDEs $(12,13,39,47,52)$ and PBBs $(50,52)$. HBCD, TBBPA, and TBPPS are most often analysed with LC coupled to an MS detector (LC-MS) $(13,37)$ or HPLC coupled to MS detector $(19,20,55)$ or UV detector $(2,22)$. LC-MS is also used to determine PBDEs, but much less often, because it is not sensitive enough to analyse higher brominated BDEs, especially the BDE-209 congener, despite the fact that it is used in the analysis of thermally unstable compounds (14).

Due to the low cost of equipment and maintenance, GC-ECD is often used in the analysis of PBDEs in various types of samples, including water, sediment, and fish. The sensitivity of GC-ECD is higher than that of GC-MS, but its main drawback is low selectivity, as analyte determination is based solely on retention time, which may not distinguish it from other halogenated compounds in the extract. The problem with co-elution of interfering halogenated compounds most often occurs with lower brominated BDEs and $\mathrm{BBs}$, while higher brominated BDEs and BBs are less likely to co-elute, because they have longer retention times than most compounds. Co-elution can be avoided with selective purification of the extract and fractionation before instrumental analysis and with the use of narrow-bore columns, which provide high resolution and rapid analysis. Another option is to use two columns of different polarity and/or GC-MS/MS or GC coupled to high-resolution mass spectrometry (GC-HRMS) as confirmatory method. For the analysis of PBDEs and PBBs it is recommended to use splitless injection, because they are present in environmental samples at very low levels. Using a 15-metre column and increasing the carrier gas flow, in turn, improves simultaneous determination of brominated BDEs, including BDE-209 (12, 14, 50).

MS is the most common technique for the analysis of organic compounds due to its high selectivity. It allows qualitative and quantitative determination of compounds based on the obtained $\mathrm{m} / \mathrm{z}$ fragments of analysed compounds.

The most common ionisation techniques for determining PBDEs in environmental samples are electron ionisation (EI), electron capture negative ionisation (ECNI), and inductively coupled plasma (ICP) ionisation. For PBBs, the techniques of choice are EI and negative chemical ionisation (NCI) $(12,31,39,40,47,49,52)$. ECNI and NCI have higher sensitivity than EI, but determination is based only on differences in retention times, and response decreases with the number of $\mathrm{Br}$ atoms. EI is more selective, because it provides more information about the structure of ionised compounds $(12,14)$. One of the most selective and sensitive techniques used in the analysis of PBBs and PBDEs is HRMS $(13,45,46,56)$. It can achieve resolution higher than 4000 without losing sensitivity to compounds with higher molecular weights, because the efficiency of ion transfer through the quadrupole mass analyser is not massdependent.

ICP-MS is primarily used to analyse inorganic compounds. Due to its excellent selectivity and sensitivity to bromine ions, it can also be combined with chromatographic techniques to detect PBDEs. $\mathrm{Br}$ is atomised and ionised in plasma at high temperature, which reduces the possibility of interference from the matrix in respect to other ionisation techniques. However, nonspectral and spectral interferences limit the application of GC-ICP-MS in the analysis of complex samples. Coupling ICP to MS/MS reduces background interference and increases accuracy, and choosing nitrous oxide over oxygen and hydrogen provides the best signal intensity (57). The advantage of the MS/MS technique is that the chemical reaction in the collision cell can be controlled.

Although for decades GC-MS has been the first choice for the analysis of organic compounds in the aquatic environment and aquatic organisms due to its high resolution, atmospheric pressure ionisation (API) has enabled the development of LC-MS and LC-MS/MS techniques with better sensitivity and selectivity and the possibility to automate determination of POPs in such complex matrices. Unlike GC, LC allows separation of polar compounds without derivatisation. However, to be detected with MS target compounds need to be in the gaseous phase, which is achieved with electrospray ionisation (ESI), atmospheric pressure photoionisation (APPI), and atmospheric pressure chemical ionisation (APCI). ESI is the most common API technique, although it allows greater matrix interference than APCI and APPI (29). Initially, HBCD was analysed with GC-ECD or GCMS, but GC columns could not separate three HBCD diastereoisomers, and they would convert into each other at temperatures above $160{ }^{\circ} \mathrm{C}(18)$. Because of similar instability at high temperature GC is also not suitable for determining TBBPA and TBBPS (19). ESI and APCI, in turn, can determine HBCD and TBBPA diastereoisomers at the same time, and ESI is more sensitive compared to APCI. APPI has showed equal sensitivity as ESI in determining HBCD and TBBPA and is also suitable for determining unstable and sensitive BDE-209 (13, 18, 20, 29, 36).

Wang et al. $(6,22,44)$ successfully combined highperformance liquid chromatography (HPLC) with an ultraviolet (UV) detector to analyse TBBPA, TBBPS, and PBBs in water samples. They used $\mathrm{C}_{18}$ reverse phase columns with a mixture of water and acetonitrile as a mobile 
Table 3 Mass fractions/concentrations of $\Sigma$ PBBs, $\Sigma$ PBDEs, TBBPA, TBBPS, and $\Sigma$ HBCD detected in different compartments of aquatic environment worldwide

\begin{tabular}{|c|c|c|c|c|c|c|c|c|}
\hline & \multirow{2}{*}{$\begin{array}{l}\text { Location } \\
\text { (number of } \\
\text { analysed } \\
\text { congeners in } \\
\text { square brackets) }\end{array}$} & \multicolumn{6}{|c|}{ Sample type } & \multirow[b]{2}{*}{ Ref. } \\
\hline & & $\begin{array}{l}\text { River water } \\
\text { (ng/L) }\end{array}$ & $\begin{array}{l}\text { Lake water } \\
\text { (ng/L) }\end{array}$ & $\begin{array}{l}\text { Seawater } \\
(\mathrm{ng} / \mathrm{L})\end{array}$ & $\begin{array}{l}\text { Wastewater } \\
\text { (ng/L) }\end{array}$ & $\begin{array}{l}\text { Sediment } \\
\text { (ng/g dw) }\end{array}$ & $\begin{array}{c}\text { Fish } \\
\left({ }^{(a n g / g ~ w w ~ o r ~}\right. \\
\text { bng/g lw) }\end{array}$ & \\
\hline \multirow{4}{*}{$\stackrel{\infty}{*}$} & $\begin{array}{l}\text { Yaner Bay, China } \\
\text { [4] } \\
\text { Sewage treatment } \\
\text { plants, China [4] }\end{array}$ & & & 112400 & $\begin{array}{c}43800- \\
44300\end{array}$ & & & (6) \\
\hline & $\begin{array}{l}\text { Three Gorges } \\
\text { Reservoar, China } \\
\text { [22] }\end{array}$ & & & & & & $0.0278-0.1557^{\mathrm{a}}$ & (62) \\
\hline & $\begin{array}{l}\text { Vaal River, South } \\
\text { Africa [2] }\end{array}$ & & & & & $3.3-18$ & & (52) \\
\hline & $\begin{array}{l}\text { North Sea, France } \\
{[5]} \\
\text { Baltic Sea, Poland } \\
\text { [5] }\end{array}$ & & & & & & $\begin{array}{c}0.00057-2.116^{\mathrm{a}} \\
0.0455-0.635^{\mathrm{a}}\end{array}$ & (50) \\
\hline \multirow{19}{*}{ 됫 } & $\begin{array}{l}\text { Yellow River, } \\
\text { China [14] }\end{array}$ & $0.491-17.4$ & & & & $0.0357-43.0$ & & (32) \\
\hline & Beijing, China [7] & $0.0236-1.255$ & & & & & & (63) \\
\hline & $\begin{array}{l}\text { Bailianghe River, } \\
\text { China [8] }\end{array}$ & & & & & & $45.8-560^{\mathrm{b}}$ & (49) \\
\hline & $\begin{array}{l}\text { Shandong } \\
\text { Province, China } \\
\text { [6] }\end{array}$ & & & & & & $0.26-1.02^{\mathrm{a}}$ & (57) \\
\hline & $\begin{array}{l}\text { Three Gorges } \\
\text { Reservoar, China } \\
\text { [27] }\end{array}$ & & & & & & $0.023-0.218$ & (62) \\
\hline & England [10] & $0.0092-0.1715$ & & & & & & (64) \\
\hline & Latvia [8] & $<\mathrm{LOD}$ & $<\mathrm{LOD}$ & & & $0.01-0.13$ & & (46) \\
\hline & $\begin{array}{l}\text { Sava River, } \\
\text { Slovenia, } \\
\text { Croatia, Serbia [7] }\end{array}$ & & & & & & $0.24-0.83^{\mathrm{a}}$ & (35) \\
\hline & $\begin{array}{l}\text { Evrotas River, } \\
\text { Greece [8] }\end{array}$ & & & & & $<\mathrm{LOD}-4.52$ & $9.32-116^{\mathrm{b}}$ & (65) \\
\hline & Ancona, Italy [15] & & & & & & $0.013-0.418^{\mathrm{a}}$ & (39) \\
\hline & $\begin{array}{l}\text { Las Tunas River, } \\
\text { Cipolleti Lake, } \\
\text { Argentina [4] }\end{array}$ & $<\operatorname{LOD}(4)$ & $<\operatorname{LOD}(4)$ & & & & & (31) \\
\hline & $\begin{array}{l}\text { Ashley and Cooper } \\
\text { River, } \\
\text { Charleston Harbor, } \\
\text { US [8] }\end{array}$ & & & & & & $0.02-3.74^{\mathrm{a}}$ & (66) \\
\hline & $\begin{array}{l}\text { Chenab River, } \\
\text { Pakistan [8] }\end{array}$ & $0.48-73.4$ & & & & $0.35-88.1$ & & (67) \\
\hline & South Korea [27] & & & $<$ LOD -0.74 & & $0.16-7.09$ & $<$ LOD $-14.68^{* b}$ & (13) \\
\hline & $\begin{array}{l}\text { Tongyeong Bay, } \\
\text { South Korea [19] }\end{array}$ & & & $1.58-6.94$ & & $2.18-307$ & $4.7-37 * \mathrm{~b}$ & (59) \\
\hline & $\begin{array}{l}\text { Ga-Selati River, } \\
\text { Africa [7] }\end{array}$ & & & & & & $<\mathrm{LOD}-0.29^{\mathrm{a}}$ & (68) \\
\hline & $\begin{array}{l}\text { Vaal River, South } \\
\text { Africa [8] }\end{array}$ & & & & & $20-98$ & & (52) \\
\hline & $\begin{array}{l}\text { Brisbane River, } \\
\text { Australia [8] }\end{array}$ & & & & & $0.01-12.4$ & & (69) \\
\hline & Antarctica [12] & & & & & & $<\mathrm{LOD}^{\mathrm{a}}$ & (70) \\
\hline
\end{tabular}




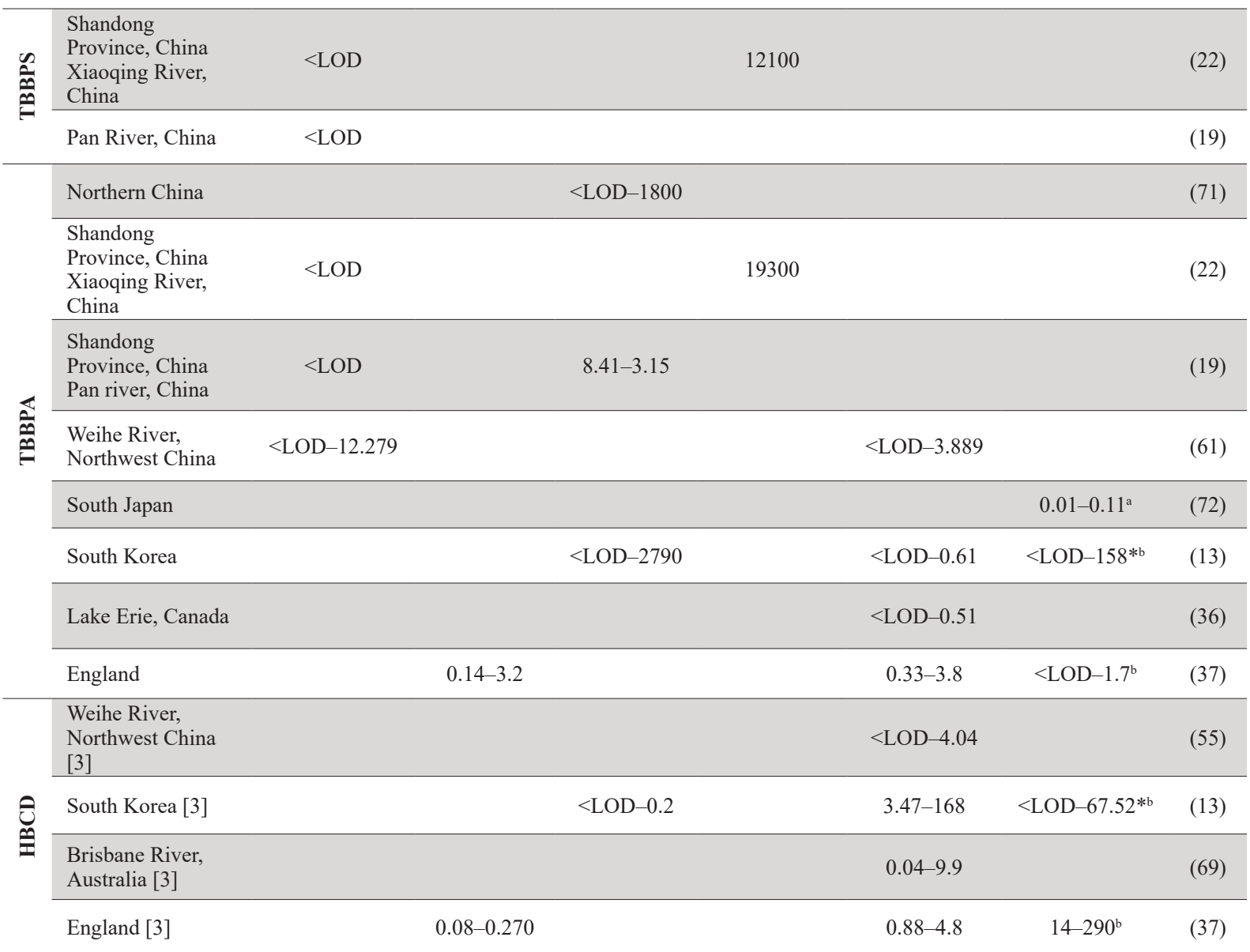

$\mathrm{dw}$ - dry weight; lw - lipid weight; ww - wet weight; * - bivalve samples; Average annual concentration of Environmental Quality Standard: PBDEs $-0.14 \mu \mathrm{g} / \mathrm{L}$ for inland; $0.014 \mu \mathrm{g} / \mathrm{L}$ for other surface waters; $0.0085 \mathrm{ng} / \mathrm{g}$ ww in biota (fish); HBCD $-0.0016 \mu \mathrm{g} / \mathrm{L}$ for inland and $0.0008 \mu \mathrm{g} / \mathrm{L}$ for other surface waters; $167 \mathrm{ng} / \mathrm{g}$ ww in biota (fish) (27)

phase for TBBPA and TBBPS and a mixture of water and methanol for PBBs. The disadvantages of this technique are low selectivity and sensitivity, and it is also necessary to concentrate the sample before analysis (19).

ICP-MS is sufficiently sensitive and selective for determination of trace PBDEs in environmental samples, but had not been used for TBBPA and TBBPS until a few years ago (19). With ICP-MS, TBBPA, TBBPS, and their derivatives can be quantified by determining ${ }^{79} \mathrm{Br}$ and ${ }^{81} \mathrm{Br}$ in the compounds. Spectral interferences of ${ }^{38} \mathrm{Ar}^{40} \mathrm{Ar}^{1} \mathrm{H}$ and ${ }^{40} \mathrm{Ar}^{40} \mathrm{Ar}^{1} \mathrm{H}$ resulting from these bromine isotopes are removed with hydrogen as reactive gas or with helium, but sensitivity is somewhat lower. As transfer of mobile phase organic solvents from HPLC to ICP can cause instability or disappearance of plasma and the formation of carbon deposits during detection of brominated compounds, the solution is to use argon with $20 \%$ oxygen as carrier to stabilise plasma $(19,58)$. As for the separation of TBBPA and TBBPS and their derivatives for HPLC, an option is to use a reverse phase $\mathrm{C}_{18}$ column and a mixture of methanol and water as the mobile phase. Better separation is ensured with gradient elution (19). Inorganic $\mathrm{Br}$ forms can be separated from organic compounds by adding $0.1 \%(v / v)$ acetic acid to the mobile phase. Adding acetic acid also reduces splitting and peak tailing problems with TBBPS. HPLC-ICP-MS/MS enables rapid, sensitive, and simultaneous quantification of TBBPA and TBBPS and their derivatives in water samples and can be applied for analysis in much more complex environmental and biological samples (19).

\section{LEVELS OF PBBS, PBDES, TBBPA, TBBPS, AND HBCD IN THE AQUATIC ENVIRONMENT}

Due to their physicochemical properties, BFRs are more often detected in sediment and aquatic biota than water (Table 3). Values above average were reported for TBBPA and TBBPS in treated wastewater from a plant which produced TBBPA and other brominated flame retardants in China (22), and - what is more surprising - for PBBs in environmental water samples, also in China. The latter may be attributed to the discharge of industrial wastewater of several large petrochemical and coating enterprises near the sampling locations (6). Wastewater treatment plants have generally been identified as a significant source of BFR, including PBDE (59) release into the environment, 
and their levels also depend on whether the water sample has passed through a purifier. For example, wastewater samples from England collected upstream of a treatment plant were reported to be nearly four times as high as downstream of the plant (169 vs $43 \mathrm{ng} / \mathrm{L}$, respectively) (12). Additionally, higher water and sediment PBDE levels were detected in parts of the rivers passing through urban and highly industrialised areas $(32,67)$. Also, aquaculture has been shown to cause higher HBCD and PBDE levels in seawater, sediment, and bivalves (13).

A comparison with Directive 2013/39/EU shows that the sums of the mass fractions of PBDEs in fish mostly exceed the established permissible values, while the values for HBCD are mostly within these limits. It is important to note that the permissible value for PBDEs has been determined based on the negative effects of only one congener (BDE-99) on rats and includes very high safety factors. Therefore, several authors proposed a new allowable value of $44 \mathrm{ng} / \mathrm{g}$, which would include the sum of all six congeners (BDE-28, -47, -99, -100, -153, and $-154)$ on the list of priority substances (60). Although an increase in EQS would seem to improve the situation, some of the detected mass fractions of PBDEs in fish would still exceed this value.

\section{CONCLUSION}

Mass concentrations/fractions of an individual BFR varies between water, sediment, or biota samples. Yet despite differences in the composition of matrices, the analysis relies on pretty much the same or similar extraction techniques. The differences are usually in extract purification, which is often not even needed for water samples.

New extraction techniques use a minimum volume of solvent or no solvent at all, which significantly shortens the time needed for analysis and lowers consumption of chemicals while achieving equal or even better extraction than classic techniques. Nevertheless, the classic Soxhlet extraction technique is still used as the benchmark for the efficiency of other extraction techniques.

PBBs and PBDEs are most often analysed with GC-MS, while LC-MS is most common for TBBPA and its TBBPS analogue. Although poorly soluble in water, LC-MS is also often used to determine HBCD, because its diastereoisomers $\alpha, \beta$, and $\gamma$ cannot be separated on GC columns, and they convert into each other above $160^{\circ} \mathrm{C}$. In general, all the methods we have reviewed here are suitable for application, as they meet the criteria provided by the EU Water Framework Directive (26).

Our brief review of recent BFR measurements clearly shows that these pollutants continue to contaminate the aquatic environment, despite use restrictions and production bans. Fortunately, the effects of bans and restrictions are visible through lower concentrations than before.

\section{Acknowledgements}

This work has been supported in part by the Croatian Science Foundation (project No. HrZZ-UIP-2017-05-6713).

\section{REFERENCES}

1. Kodavanti PRS, Stoker TE, Fenton SE. Brominated flame retardants. In: Gupta RC, editor. Reproductive and developmental toxicology. $2^{\text {nd }}$ ed. Orlando (FL): Academic Press Incorporated; 2017. p. 681-710.

2. Hu L, Zhou T, Luo D, Feng J, Tao Y, Zhou Y, Mei S. Bioaccumulation of tetrabromobisphenol A in a laboratorybased fish-water system based on selective magnetic molecularly imprinted solid-phase extraction. Sci Total Environ 2019;650:1356-62. doi: 10.1016/j. scitotenv.2018.09.002

3. Klinčić D, Dvoršćak M, Jagić K, Mendaš G, Herceg Romanić S. Levels and distribution of polybrominated diphenyl ethers in humans and environmental compartments: a comprehensive review of the last five years of research. Environ Sci Pollut Res Int 2020;27:5744-58. doi: 10.1007/s11356-020-07598-7

4. Kodavanti PRS, Loganathan BG. Polychlorinated biphenyls, polybrominated biphenyls, and brominated flame retardants. In: Gupta RC, editor. Biomarkers in toxicology. Amsterdam: Elsevier Inc.; 2014. p. 433-50.

5. Cowell WJ, Sjödin A, Jones R, Wang Y, Wang S, Herbstman JB. Temporal trends and developmental patterns of plasma polybrominated diphenyl ether concentrations over a 15-year period between 1998 and 2013. J Expo Sci Environ Epidemiol 2019;29:49-60. doi: 10.1038/s41370-018-0031-3

6. Wang X, Du T, Wang J, Kou H, Du X. Determination of polybrominated biphenyls in environmental water samples by ultrasound-assisted dispersive liquid-liquid microextraction followed by high-performance liquid chromatography. Microchem J 2019;148:85-91. doi: 10.1016/j.microc.2019.04.065

7. UNEP. Stockholm Convention [displayed 17 November 2021]. Available at http://www.pops.int/TheConvention/ Overview/tabid/3351/Default.aspx

8. US EPA. Technical Fact Sheet - Polybrominated Biphenyls (PBBs) 2017 [displayed 17 November 2021]. Available at https:/www.epa.gov/sites/default/files/2017-12/documents/ ffrro_factsheet_pbb_11-16-17_508.pdf

9. de Wit CA, Herzke D, Vorkamp K. Brominated flame retardants in the Arctic environment - trends and new candidates. Sci Total Environ 2010;408:2885-918. doi: 10.1016/j.scitotenv.2009.08.037

10. Yun SH, Addink R, McCabe JM, Ostaszewski A, MackenzieTaylor D, Taylor AB, Kannan K. Polybrominated diphenyl ethers and polybrominated biphenyls in sediment and floodplain soils of the Saginaw River watershed, Michigan, USA. Arch Environ Contam Toxicol 2008;55:1-10. doi: 10.1007/s00244-007-9084-3

11. UNEP. Stockholm Convention. Guidance for the inventory of polybrominated diphenyl ethers (PBDEs) listed under the Stockholm Convention on POPs, 20152017 [displayed 17 November 2021]. Available at http://chm.pops.int/ I m p le me n t a t i o n / N I P s / G u i d a n c e / GuidancefortheinventoryofPBDEs/tabid/3171/Default.aspx 
12. Komolafe O, Bowler B, Dolfing J, Mrozik W, Davenport RJ. Quantification of polybrominated diphenyl ether (PBDE) congeners in wastewater by gas chromatography with electron capture detector (GC-ECD). Anal Methods 2019;11:3474-82. doi: 10.1039/c9ay00266a

13. Gu S-Y, Ekpeghere KI, Kim H-Y, Lee I-S, Kim D-H, Choo $\mathrm{G}$, Oh J-E. Brominated flame retardants in marine environment focused on aquaculture area: Occurrence, source and bioaccumulation. Sci Total Environ 2017;601-602:118291. doi: 10.1016/j.scitotenv.2017.05.209

14. Kierkegaard A, Sellström U, McLachlan MS. Environmental analysis of higher brominated diphenyl ethers and decabromodiphenyl ethane. J Chromatogr A 2009;1216:364 75. doi: $10.1016 /$ j.chroma.2008.05.058

15. García-Córcoles MT, Rodríguez-Gómez R, de AlarcónGómez B, Çipa M, Martín-Pozo L, Kauffmann JM, ZafraGómez A. Chromatographic methods for the determination of emerging contaminants in natural water and wastewater samples: A review. Crit Rev Anal Chem 2019;49:160-86. doi: 10.1080/10408347.2018.1496010

16. Covaci A, Voorspoels S, Abdallah MAE, Geens T, Harrad S, Law RJ. Analytical and environmental aspects of the flame retardant tetrabromobisphenol-A and its derivatives. J Chromatogr A 2009;1216:346-63. doi: 10.1016/j. chroma.2008.08.035

17. Zhou H, Yin N, Faiola F. Tetrabromobisphenol A (TBBPA): A controversial environmental pollutant. J Environ Sci (China) 2020;97:54-66. doi: 10.1016/j.jes.2020.04.039

18. Quevauviller P, Roose P. Verreet G, editors. Chemical Marine Monitoring: Policy Framework and Analytical Trends. Hoboken (NJ): John Wiley \& Sons; 2011.

19. Liu L, Liu A, Zhang Q, Shi J, He B, Yun Z, Jiang G. Determination of tetrabromobisphenol-A/S and their main derivatives in water samples by high performance liquid chromatography coupled with inductively coupled plasma tandem mass spectrometry. J Chromatogr A 2017;1497:816. doi: 10.1016/j.chroma.2017.03.040

20. Yu Y, Zhu X, Zhu J, Li L, Zhang X, Xiang M, Ma R, Yu L, Yu Z, Wang Z. Rapid and simultaneous analysis of tetrabromobisphenol $\mathrm{A}$ and hexabromocyclododecane in water by direct immersion solid phase microextraction: Uniform design to explore factors. Ecotoxicol Environ Saf 2019;176:364-9. doi: 10.1016/j.ecoenv.2019.03.104

21. Włuka A, Woźniak A, Woźniak E, Michałowicz J. Tetrabromobisphenol A, terabromobisphenol S and other bromophenolic flame retardants cause cytotoxic effects and induce oxidative stress in human peripheral blood mononuclear cells (in vitro study). Chemosphere 2020;261:127705. doi: 10.1016/j.chemosphere.2020.127705

22. Wang X, Liu J, Liu A, Liu Q, Du X, Jiang G. Preparation and evaluation of mesoporous cellular foams coating of solid-phase microextraction fibers by determination of tetrabromobisphenol $\mathrm{A}$, tetrabromobisphenol $\mathrm{S}$ and related compounds. Anal Chim Acta 2012;753:1-7. doi: 10.1016/j. aca.2012.09.030

23. Sarpong KA, Zhang K, Luan Y, Cao Y, Xu W. Development and application of a novel electrochemical sensor based on AuNPS and difunctional monomer-MIPs for the selective determination of Tetrabromobisphenol-S in water samples. Microchem J 2020;154:104526. doi: 10.1016/j. microc.2019.104526
24. Palace VP, Pleskach K, Halldorson T, Danell R, Wautier K, Evans B, Alaee M, Marvin C, Tomy GT. Biotransformation enzymes and thyroid axis disruption in juvenile rainbow trout (Oncorhynchus mykiss) exposed to hexabromocyclododecane diastereoisomers. Environ Sci Technol 2008;42:1967-72. doi: 10.1021/es702565h

25. van der Ven LTM, van de Kuil T, Leonards PEG, Slob W, Lilienthal H, Litens S, Herlin M, Håkansson H, Cantón RF, van den Berg M, Visser TJ, van Loveren H, Vos JG, Piersma AH. Endocrine effects of hexabromocyclododecane (HBCD) in a one-generation reproduction study in Wistar rats. Toxicol Lett 2009;185:51-62. doi: 10.1016/j.toxlet.2008.12.003

26. Directive 2000/60/EC of the European Parliament and of the Council of 23 October 2000 establishing a framework for Community action in the field of water policy [displayed 19 November 2021]. Available at https://eur-lex.europa.eu/ le g a 1 - c o n t e n t/ E N / T X T / H T M L/? uri $=$ CELEX:32000L0060\&from $=E N$

27. Directive 2013/39/EU of the European Parliament and of the Council of 12 August 2013 amending Directives 2000/60/ EC and 2008/105/EC as regards priority substances in the field of water policy [displayed 19 November 2021]. Available at https://eur-lex.europa.eu/legal-content/EN/TXT/ HTML/?uri=CELEX:32013 L0039\&from=EN

28. Wu Z, Han W, Yang X, Li Y, Wang Y. The occurrence of polybrominated diphenyl ether (PBDE) contamination in soil, water/sediment, and air. Environ Sci Pollut Res Int 2019;26:23219-41. doi: 10.1007/s11356-019-05768-w

29. Bussy U, Li K, Li W. Application of liquid chromatographytandem mass spectrometry in quantitative bioanalyses of organic molecules in aquatic environment and organisms. Environ Sci Pollut Res Int 2016;23:9459-79. doi: 10.1007/ s11356-016-6433-7

30. Stapleton HM. Brominated Flame Retardants: Assessing DecaBDE Debromination in the Environment, 2006 [displayed 17 November 2021]. Available at http://www. env-health.org/IMG/pdf/Debromination paper_04052006_2_.pdf

31. Fontana AR, Wuilloud RG, Martínez LD, Altamirano JC. Simple approach based on ultrasound-assisted emulsificationmicroextraction for determination of polibrominated flame retardants in water samples by gas chromatography-mass spectrometry. J Chromatogr A 2009;1216:147-53. doi: 10.1016/j.chroma.2008.11.034

32. Pei J, Yao H, Wang H, Li H, Lu S, Zhang X, Xiang X. Polybrominated diphenyl ethers (PBDEs) in water, surface sediment, and suspended particulate matter from the Yellow River, China: Levels, spatial and seasonal distribution, and source contribution. Mar Pollut Bull 2018;129:106-13. doi: 10.1016/j.marpolbul.2018.02.017

33. Feng Z, Wang Y, Yang L, Sun T. Coupling mesoporous imprinted polymer based DGT passive samplers and HPLC: A new tool for in-situ selective measurement of low concentration tetrabromobisphenol A in freshwaters. Sci Total Environ 2019;685:442-50. doi: 10.1016/j. scitotenv.2019.05.297

34. Covaci A, Voorspoels S, Ramos L, Neels H, Blust R. Recent developments in the analysis of brominated flame retardants and brominated natural compounds. J Chromatogr A 2007;1153:145-71. doi: 10.1016/j.chroma.2006.11.060

35. Novak P, Zuliani T, Milačič R, Ščančar J. Development of an analytical method for the determination of polybrominated 
diphenyl ethers in mussels and fish by gas chromatography - Inductively coupled plasma mass spectrometry. J Chromatogr A 2017;1524:179-87. doi: 10.1016/j. chroma.2017.09.059

36. Chu S, Haffner GD, Letcher RJ. Simultaneous determination of tetrabromobisphenol A, tetrachlorobisphenol A, bisphenol $\mathrm{A}$ and other halogenated analogues in sediment and sludge by high performance liquid chromatography-electrospray tandem mass spectrometry. J Chromatogr A 2005;1097:2532. doi: 10.1016/j.chroma.2005.08.007

37. Harrad S, Abdallah MAE, Rose NL, Turner SD, Davidson TA. Current-use brominated flame retardants in water, sediment, and fish from English lakes. Environ Sci Technol 2010;44:5318. doi: 10.1021/es101746s

38. Suzuki S, Hasegawa A. Determination of hexabromocyclododecane diastereoisomers and tetrabromobisphenol $\mathrm{A}$ in water and sediment by liquid chromatography/mass spectrometry. Anal Sci 2006;22:469 74. doi: 10.2116/analsci.22.469

39. Piersanti A, Tavoloni T, Bastari E, Lestingi C, Romanelli S, Rossi R, Saluti G, Moretti S, Galarini R. A GC-EI-MS/MS method for the determination of 15 polybrominated diphenyl ethers (PBDEs) in fish and shellfish tissues. Food Anal Methods 2018;11:355-66. doi: 10.1007/s12161-017-1006-Z

40. Marć M, Wieczorek PP. Application potential of dummy molecularly imprinted polymers as solid-phase extraction sorbents for determination of low-mass polybrominated diphenyl ethers in soil and sediment samples. Microchem J 2019;144:461-8. doi: 10.1016/j.microc.2018.09.035

41. Wang X, Huang P, Ma X, Wang H, Lu X, Du X. Preparation and evaluation of magnetic core-shell mesoporous molecularly imprinted polymers for selective adsorption of tetrabromobisphenol S. Talanta 2017;166:300-5. doi: 10.1016/j.talanta.2017.01.067

42. Serôdio P, Cabral MS, Nogueira JMF. Use of experimental design in the optimization of stir bar sorptive extraction for the determination of polybrominated diphenyl ethers in environmental matrices. J Chromatogr A 2007;1141:259-70. doi: 10.1016/j.chroma.2006.12.011

43. Jabari H, Telgheder U, Bader N, Alshelmani N. Stir bar sorptive extraction as a sample preparation technique for chromatographic analysis: An overview. Asian J Nanosci Mater 2018;1:56-62. doi: 10.26655/AJNANOMAT.2018.3.2

44. Wang X, Liu J, Liu Q, Du X, Jiang G. Rapid determination of tetrabromobisphenol A and its main derivatives in aqueous samples by ultrasound-dispersive liquid-liquid microextraction combined with high-performance liquid chromatography. Talanta 2013;116:906-11. doi: 10.1016/j. talanta.2013.08.011

45. Wang P, Zhang Q, Wang Y, Wang T, Li X, Ding L, Jiang G. Evaluation of Soxhlet extraction, accelerated solvent extraction and microwave-assisted extraction for the determination of polychlorinated biphenyls and polybrominated diphenyl ethers in soil and fish samples. Anal Chim Acta 2010;663:43-8. doi: 10.1016/j.aca.2010.01.035

46. Aigars J, Suhareva N, Poikane R. Distribution of polybrominated diphenyl ethers in sewage sludge, sediments, and fish from Latvia. Environments 2017;4:12. doi: 10.3390/ environments 4010012

47. Alonso MB, Eljarrat E, Gorga M, Secchi ER, Bassoi M, Barbosa L, Bertozzi CP, Marigo J, Cremer M, Domit C, Azevedo AF, Dorneles PR, Torres JPM, Lailson-Brito J,
Malm O, Barceló D. Natural and anthropogenically-produced brominated compounds in endemic dolphins from Western South Atlantic: another risk to a vulnerable species. Environ Pollut 2012;170:152-60. doi: 10.1016/j.envpol.2012.06.001

48. He W, Chen Y, Yang C, Liu W, Kong X, Qin N, He Q, Xu F. Optimized multiresidue analysis of organic contaminants of priority concern in a daily consumed fish (Grass Carp). J Anal Methods Chem 2017;2017:9294024. doi: $10.1155 / 2017 / 9294024$

49. Li N, Luo J, Na S, Du S, Wang X, Hai R. Determination of polybrominated diphenyl ethers (PBDEs) in freshwater fish around a deca-brominated diphenyl ether (deca-BDE) production facility by Gas Chromatography-Mass Spectrometry (GC-MS). Anal Lett 2019;52:2951-60. doi: 10.1080/00032719.2019.1632336

50. Gieroń J, Grochowalski A, Chrzaszcz R. PBB levels in fish from the Baltic and North seas and in selected food products from Poland. Chemosphere 2010;78:1272-8. doi: 10.1016/j. chemosphere.2009.12.031

51. Morris S, Allchin CR, Zegers BN, Haftka JJH, Boon JP, Belpaire C, G Leonards PEG, Van Leeuwen SPJ, De Boer J. Distribution and fate of HBCD and TBBPA brominated flame retardants in North Sea estuaries and aquatic food webs. Environ Sci Technol 2004;38:5497-504. doi: 10.1021/ es049640i

52. Chokwe TB, Magubane MN, Abafe OA, Okonkwo JO, Sibiya IV. Levels, distributions, and ecological risk assessments of polybrominated diphenyl ethers and alternative flame retardants in river sediments from Vaal River, South Africa. Environ Sci Pollut Res Int 2019;26:7156-63. doi: 10.1007/ s11356-018-04063-4

53. Albero B, Sánchez-Brunete C, García-Valcárcel AI, Pérez RA, Tadeo JL. Ultrasound-assisted extraction of emerging contaminants from environmental samples. TrAC - Trends Anal Chem 2015;71:110-8. doi: 10.1016/j.trac.2015.03.015

54. Wu HH, Chen HC, Ding WH. Combining microwaveassisted extraction and liquid chromatography-ion-trap mass spectrometry for the analysis of hexabromocyclododecane diastereoisomers in marine sediments. J Chromatogr A 2009;1216:7755-60. doi: 10.1016/j.chroma.2009.09.001

55. Wang X, Yuan X, Yang S, Zhao Y. Concentrations, distributions, and risk assessment of HBCD in sediment in the Weihe River Basin in Northwest China. Int J Environ Res Public Health 2018;15:2340. doi: 10.3390/ijerph15112340

56. Fernandes AR, Mortimer D, Holmes M, Rose M, Zhihua L, Huang X, Smith F, Panton S, Marshall L. Occurrence and spatial distribution of chemical contaminants in edible fish species collected from UK and proximate marine waters. Environ Int 2018;114:219-30. doi: 10.1016/j. envint.2018.02.047

57. Zhang C, Li X, Li H, Chen Y, Ma T, Li X, Gao Y, Zhang Q. Determination of polybrominated diphenyl ethers in fish tissue using gas chromatography-isotope dilution tandem inductively coupled plasma mass spectrometry with a massshift mode. Anal Chim Acta 2019;1075:38-48. doi: 10.1016/j. aca.2019.05.006

58. Lorenzo M, Campo J, Picó Y. Analytical challenges to determine emerging persistent organic pollutants in aquatic ecosystems. TrAC - Trends Anal Chem 2018;103:137-55. doi: 10.1016/j.trac.2018.04.003

59. Lee HJ, Jeong HJ, Jang YL, Kim GB. Distribution, accumulation, and potential risk of polybrominated diphenyl 
ethers in the marine environment receiving effluents from a sewage treatment plant. Mar Pollut Bull 2018;129:364-9. doi: 10.1016/j.marpolbul.2018.02.050

60. Eljarrat E, Barceló D. How do measured PBDE and HCBD levels in river fish compare to the European Environmental Quality Standards? Environ Res 2018;160:203-11. doi: 10.1016/j.envres.2017.09.011

61. Wang X, Li C, Yuan X, Yang S. Contamination level, distribution characteristics, and ecotoxicity of tetrabromobisphenol a in water and sediment from Weihe River Basin, China. Int J Environ Res Public Health 2020;17:3750. doi: 10.3390/ijerph17113750

62. Ding X, Liu J, Wen W. Brominated flame retardants in edible fishes from Three Gorges reservoir, China. Tecnol Cienc Agua 2019;10:46-65. doi: 10.24850/j-tyca-2019-04-03

63. Shao Y, Han S, Ma L, Luo M, Yang G, Liu W, DianDou X. Polybrominated diphenyl ethers in surface waters around Beijing: Occurrence, distribution and sources. Appl Geochem 2018;98:58-64. doi: 10.1016/j.apgeochem.2018.09.011

64. Yang C, Harrad S, Abdallah MAE, Desborough J, Rose NL, Turner SD, Davidson TA, Goldsmith B. Polybrominated diphenyl ethers (PBDEs) in English freshwater lakes, 2008-2012. Chemosphere 2014;110:41-7. doi: 10.1016/j. chemosphere.2014.03.028

65. Giulivo M, Capri E, Kalogianni E, Milacic R, Majone B, Ferrari F, Eljarrat E, Barcel D. Occurrence of halogenated and organophosphate flame retardants in sediment and fish samples from three European river basins. Sci Total Environ 2017;586:782-91. doi: 10.1016/j.scitotenv.2017.02.056

66. Fair PA, White ND, Wolf B, Arnott SA, Kannan K, Karthikraj R, Vena JE. Persistent organic pollutants in fish from Charleston Harbor and tributaries, South Carolina, United
States: A risk assessment. Environ Res 2018;167:598-613. doi: 10.1016/j.envres.2018.08.001

67. Mahmood A, Malik RN, Li J, Zhang G. Distribution, congener profile, and risk of polybrominated diphenyl ethers and dechlorane plus in water and sediment from two tributaries of the Chenab River, Pakistan. Arch Environ Contam Toxicol 2015;68:83-91. doi: 10.1007/s00244-0140074-y

68. Govaerts A, Verhaert V, Covaci A, Jaspers VLB, Kristian O, Addo-Bediako A, Jooste A, Bervoets L. Distribution and bioaccumulation of POPs and mercury in the Ga-Selati River (South Africa) and the rivers Gudbrandsdalslågen and Rena (Norway). Environ Int 2018;121:1319-30. doi: 10.1016/j. envint.2018.10.058

69. Anim AK, Drage DS, Goonetilleke A, Mueller JF, Ayoko GA. Distribution of PBDEs, HBCDs and PCBs in the Brisbane River estuary sediment. Mar Pollut Bull 2017;120:165-73. doi: 10.1016/j.marpolbul.2017.05.002

70. Markham E, Brault EK, Khairy M, Robuck AR, Goebel ME, Cantwell MG, Dickhut RM, Lohmann R. Time trends of polybrominated diphenyl ethers (PBDEs) in Antarctic biota. ACS Omega 2018;3:6595-604. doi: 10.1021/ acsomega. 8 b00440

71. Yin J, Meng Z, Zhu Y, Song M, Wang H. Dummy molecularly imprinted polymer for selective screening of trace bisphenols in river water. Anal Methods 2011;3:173-80. doi: 10.1039/ c0ay00540a

72. Ashizuka Y, Nakagawa R, Hori T, Yasutake D, Tobiishi K, Sasaki K. Determination of brominated flame retardants and brominated dioxins in fish collected from three regions of Japan. Mol Nutr Food Res 2008;52:273-83. doi: 10.1002/ mnfr.200700110

\section{Analitika bromiranih usporivača gorenja u vodenom okolišu - pregledni rad}

Najčešće korišteni, a posljedično i analizirani bromirani usporivači gorenja su polibromirani bifenili (PBB), polibromirani difenil eteri (PBDE), tetrabromobisfenol A (TBBPA), tetrabromobisfenol S (TBBPS) i heksabromociklododekan (HBCD). Navedeni spojevi smatraju se postojanim organskim zagađivalima, a s obzirom na to da su široko rasprostranjeni u okolišu i dokazano imaju niz negativnih štetnih učinaka na ljudsko zdravlje, proizvodnja i upotreba većine njih strogo je zabranjena. Vodeni je okoliš izložen ovim spojevima njihovim taloženjem iz atmosfere, mulja otpadnih voda, postrojenja za pročišćavanje otpadnih voda i ispiranjem odlagališta otpada, a ovisno o fizikalno-kemijskim svojstvima pojedinog spoja prisutan je u većim koncentracijama/udjelima u određenom dijelu vodenog okoliša. Više razine pronalaze se u područjima s razvijenom industrijom i poljoprivredom te u blizini odlagališta otpada. Cilj ovoga rada bio je detaljno i sažeto objasniti analitiku navedenih spojeva u vodenom okolišu - vodi, sedimentu i vodenim organizmima. Analitika spojeva bromiranih usporivača gorenja iznimno je važna kako bi se pouzdano mogle odrediti njihove razine i raspodjela u vodenom okolišu te na temelju dobivenih podataka procijeniti izloženost ljudi ovim spojevima. Posebno je zabrinjavajuće što zbroj masenih udjela spojeva PBDE u ribi uglavnom prelazi dopuštene vrijednosti.

KLJUČNE RIJEČI: HBCD; heksabromociklododekan; PBB; polibromirani bifenili; PBDE; polibromirani difenil eteri; postojana organska zagađivala; TBBPA; tetrabromobisfenol A; TBBPS; tetrabromobisfenol S 